\title{
COMPARISON OF PREDICTED FAILURE AREA AROUND THE BOREHOLES IN THE STRIKE-SLIP FAULTING STRESS REGIME WITH HOEK-BROWN AND FAIRHURST GENERALIZED CRITERIA
}

\author{
Ali LAKIROUHANI®1, Mohammad BAHREHDAR (1) \\ Jurgis MEDZVIECKAS ${ }^{2 *}$ Romualdas KLIUKAS (1) 3 \\ ${ }^{1}$ Department of Civil Engineering, Faculty of Engineering, University of Zanjan, Zanjan, Iran \\ ${ }^{2}$ Department of Reinforced Concrete Structures and Geotechnics, Vilnius Gediminas Technical University, \\ Sauletekio al. 11, LT-10223 Vilnius, Lithuania \\ ${ }^{3}$ Department of Applied Mechanics, Vilnius Gediminas Technical University, \\ Sauletekio al. 11, LT-10223 Vilnius, Lithuania
}

Received 31 March 2021; accepted 18 May 2021

\begin{abstract}
Breakout is a shear failure due to compression that forms around the borehole due to stress concentration. In this paper, the breakout theory model is investigated by combining the equilibrium elasticity equations of stress around the borehole with two Hoek-Brown and Fairhurst generalized fracture criteria, both of which are based on the Griffith criterion. This theory model provides an explicit equation for the breakout failure width, but the depth of failure is obtained by solving a quartic equation. According to the results and in general, in situ stresses and rock strength characteristics are effective in developing the breakout failure area, As the ratio of in-situ stresses increases, the breakout area becomes deeper and wider. Because in the shear zone, the failure envelope of the Fairhurst criterion is lower than the Hoek-Brown failure criterion, the Fairhurst criterion provides more depth for breakout than the Hoek-Brown criterion. However, due to the same compressive strength of the rock in these two criteria, the same failure width for breakout is obtained from these two criteria. Also, the results obtained for the depth of failure from the theoretical model based on the Fairhurst criterion are in good agreement with the laboratory results on Westerly granite.
\end{abstract}

Keywords: borehole breakout, damage zone, Hoek-Brown failure criterion, Fairhurst generalized fracture criterion, in situ stress, Westerly granite.

\section{Introduction}

Drilling a borehole in the ground disrupts the distribution of initial stresses around it. Secondary stresses or induced stresses around the borehole can be high enough to cause intense stress concentration. Depending on the amount of in-situ stresses in some places around the borehole, secondary stresses exceed the compressive and tensile strength of the rock, causing failure in the rock. A failure known as a borehole breakout occurs as a result of the concentration of compressive stress around the borehole and can occur through a tensile or shear mechanism. In a vertical bore in the strike-slip faulting stress regime, that is, the state in which $\sigma_{h}<\sigma_{v}<\sigma_{H}$, Shear failure occurs parallel to the axis of the borehole and in its classic form as a wide breakout. In this case, in the horizontal planes perpendicular to the axis of the vertical borehole, the breakout failure zone is formed along the minor in situ stress (Carr, 1974; Bell \& Gough, 1979; Zoback et al., 1985). This form of failure has also been confirmed by laboratory studies (Mastin, 1984; Haimson \& Herrick, 1985, 1986). Therefore, borehole breakout can be used as an indicator to study the direction of in situ stresses (Bell \& Gough, 1979; Hickman \& Zoback, 2004; Shamir \& Zoback, 1992). Breakout in large form causes borehole instability, but just as hydraulic fracturing is effective in evaluating in situ stresses (Lakirouhani et al., 2016), the geometric characteristics of breakout can also be useful in estimating the direction and values of in situ stresses in the earth's crust (Gough \& Bell, 1982; Zoback et al., 1985; Herrick \& Haimson, 1994; Brudy et al., 1997; Song \& Haimson, 1997; Zoback et al., 2003). Nearly $21 \%$ of the

*Corresponding author. E-mail: jurgis.medzvieckas@vilniustech.lt 
stress orientation indices in the World Stress Map database were identified from borehole breakouts (Reinecker et al., 2005; Huber et al., 1997). Lin et al. (2020) also recently developed a machine learning technique for estimating horizontal in situ stresses using vertical borehole breakout information.

Borehole breakout was seen in the Witwatersrand gold mine in South Africa about 50 years ago (Leeman, 1964a, 1964b, 1964c). Afterward, it was observed in oil wells (Cox, 1972). Then Carr (1974) showed that breakouts occur along minor in situ stresses. This was confirmed by Bell and Gough (1979) and Zoback et al. (1985). Bell and Gough (1979) observed a systematic correlation between the borehole breakout direction and the direction of the minor regional in situ stress in Alberta, Canada. Although some researchers found that borehole breakout shape and depth in vertical boreholes are dependent upon the minimum and maximum in-situ stresses, but some other researchers proposed that the in situ stresses could also be estimated through borehole breakout shape (Martin et al., 1994).

Gough and Bell (1982) showed that the breakout is formed by two tangential shear fractures on the borehole wall, each of which has an angle of $\pi / 4-\phi / 2$ with respect to the major principal stress direction, where $\phi$ represents the internal friction angle of the rock.

Zoback et al. (1985) showed that the ratio of in situ stresses on a plane perpendicular to the borehole axis may be determined by breakout geometry, but it is not possible to accurately estimate their values.

It was also shown that the breakout formed in the shape of a "dog ear" in crystalline rocks and limestones and low porosity sandstones, could be through a tensile (Lee \& Haimson, 1993; Okland \& Cook, 1998) or shear mechanism (Haimson \& Song, 1993; Syarifuddin \& Busono, 1999).

As the microstructure of the rock has a great impact on its strength and physical properties (Lakirouhani et al., 2020), various laboratory studies have shown that mineral composition, and grain shape and porosity are effective in the form of breakout failure. For this reason, three different forms of failure have been observed for breakout: spiral-shaped (van den Hoek, 2001), V-shaped (Haimson \& Lee, 2004), and slot-shaped (Haimson, 2007).

The theoretical-numerical analysis of progressive Vshaped breakout is also investigated using the finite/discrete element method (Wu et al., 2017) and boundary element method (Cheng et al., 2019). Abdelghany et al. (2021) used the concept of depth of damage to study borehole stability in the Gulf of Suez.

Using the three criteria of Mohr-Coulomb, MogiCoulomb, and modified Lade, Yousefian et al. (2020) determined the optimal drilling direction with the help of the concept of failure zone. Delonca and Vallejos (2020) proposed a generalized failure criterion to investigate the scale effect on failure around the borehole.

Setiawan and Zimmerman (2018) combined the MogiCoulomb criterion with Jaeger plane of weakness theory to analyze the effects of strength anisotropy on borehole instability and breakout.
Shalev et al. (2021) by laboratory experiments and three-dimensional numerical models on granite and arcose showed that models based on strength and stress alone are not sufficient to investigate the borehole stability and breakout.

\section{Definition of the problem}

The purpose of this paper is the theoretical analysis of breakout failure around a borehole in a homogeneous and isotropic elastic medium with Hoek-Brown and Fairhurst criteria. The Fairhurst criterion is a generalized of the Griffith failure criterion, and the basis of the Hoek-Brown criterion is also the Griffith criterion. But as can be seen below, one of the important differences between these two criteria is in predicting the tensile strength of rock.

In this article, theoretical models are two-dimensional and assuming a strike-slip faulting stress regime in the ground that is $\sigma_{h}<\sigma_{v}<\sigma_{H}$. The stress distribution around the borehole is based on the Kirsch relationships given in the next section. By combining Hoek-Brown and Fairhurst failure criteria with Kirsch relations, the theoretical model of breakout geometry around the borehole has been developed.

In the next section, Carrara marble specifications have been used to evaluate the results and compare the two failure models with each other. For this purpose, first the failure envelope of both criteria is drawn based on the laboratory specifications of this rock and then the area of failure around the borehole is drawn and compared based on both criteria. In the other part of the paper, due to the existence of breakout laboratory results for Westerly granite, the results obtained from the theoretical model with Westerly granite specifications are compared with the laboratory results, which is followed by the conclusion in the final section.

\section{Distribution of stress around the borehole and breakout}

A borehole with radius $a$ in an elastic, homogeneous and isotropic environment under non-isotropic stresses of $\sigma_{H}$, $\sigma_{h}$ is considered (Figure 1). The stresses around the borehole according to the Kirsch relations are obtained as follows (Jaeger et al., 2009; Abbas et al., 2019):

$\left\{\begin{array}{l}\sigma_{r r}=\frac{1}{2}\left[\left(\sigma_{H}+\sigma_{h}\right)\left(1-\frac{a^{2}}{r^{2}}\right)-\left(\sigma_{H}-\sigma_{h}\right)\left(1-4 \frac{a^{2}}{r^{2}}+\frac{3 a^{4}}{r^{4}}\right) \cos 2 \theta\right] \\ \sigma_{\theta \theta}=\frac{1}{2}\left[\left(\sigma_{H}+\sigma_{h}\right)\left(1+\frac{a^{2}}{r^{2}}\right)+\left(\sigma_{H}-\sigma_{h}\right)\left(1+\frac{3 a^{4}}{r^{4}}\right) \cos 2 \theta\right] \\ \tau_{r \theta}=\frac{1}{2}\left[\left(\sigma_{H}-\sigma_{h}\right)\left(1+\frac{2 a^{2}}{r^{2}}-\frac{3 a^{4}}{r^{4}}\right) \sin 2 \theta\right]\end{array}\right.$.

In these relations $a$ is the radius of the borehole and $\mathrm{r}$ is the distance of the point at which the stresses are calculated from the center of the borehole. $\theta$ is the angle at 


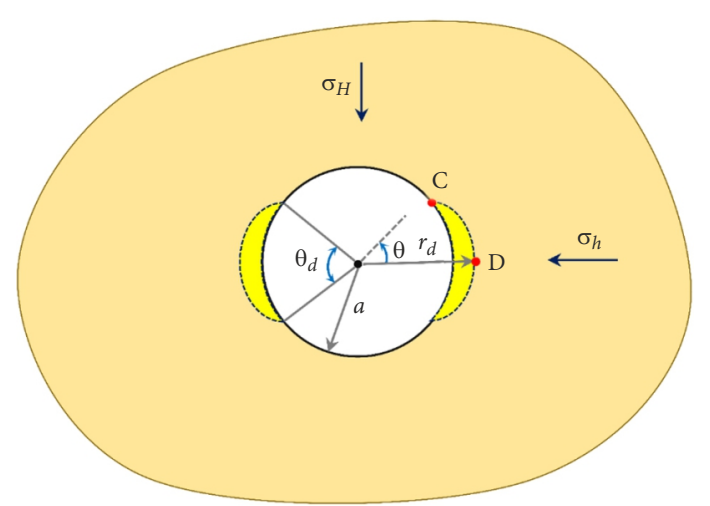

Figure 1. Schematic of breakout failure around the borehole

which the stress is calculated, with the direction of the minor in situ stress. $\sigma_{H}$ and $\sigma_{h}$ are major and minor in situ stresses, respectively.

Around the borehole and along the minor in situ stress, a compressive stress concentration occurs which leads to the formation of a breakout failure zone. This area is shown in Figure 1 in yellow. In this paper, the depth of this area along the minor in situ stress is determined by $r_{d}$ and its width by $\theta_{d}$.

\section{Theoretical model of breakout failure based on Fairhurst generalized fracture criterion}

Based on Brazilian tensile strength tests, Fairhurst (1964) presented the generalized Griffiths criterion as a function with two relations (Hoek \& Martin, 2014):

$\left\{\begin{array}{l}\frac{\left(\sigma_{1}-\sigma_{3}\right)^{2}}{\left(\sigma_{1}+\sigma_{3}\right)}=-2 \sigma_{t}(w-1)^{2}\left[1+\frac{2 \sigma_{t}}{\sigma_{1}+\sigma_{3}}\left(\left(\frac{w-1}{2}\right)^{2}-1\right)\right] \\ \sigma_{3}=\sigma_{t} \text { if } w(w-2) \sigma_{3}+\sigma_{1} \leq 0\end{array}\right.$

if $w(w-2) \sigma_{3}+\sigma_{1}>0$,

where:

$$
w=\sqrt{\frac{\sigma_{c}}{\left|\sigma_{t}\right|}+1}=\sqrt{n+1},
$$

where $\sigma_{1}$ and $\sigma_{3}$ are maximum and minimum principal stresses, respectively and $\sigma_{t}$ is tensile strength of rock and is assumed to be negative. This criterion can also be written in the simplified form below:

$$
\left(\sigma_{1}-\sigma_{3}\right)^{2}=-\sigma_{t} A\left(\sigma_{1}+\sigma_{3}\right)-2 A B \sigma_{t}^{2},
$$

where $A=2(w-1)^{2}$ and $B=((w-1) / 2)^{2}-1$.

This criterion in the main stresses space and in the $\left(\tau-\sigma_{n}\right)$ space is shown in the Figure 2.

Therefore, the failure function in this criterion is defined as follows:

$$
F=\left(\sigma_{1}-\sigma_{3}\right)^{2}+\sigma_{t} A\left(\sigma_{1}+\sigma_{3}\right)+2 A B \sigma_{t}^{2}=0 .
$$

As shown in Figure 1, the failure zone has two characteristics, first, the width of the breakout represented by $\theta_{d}$ and second, the depth of the failure zone along the minor in situ stress or $r_{d}$. In this section, the goal is to obtain these two characteristics.

To get the width of the breakout in the borehole wall, i.e. $\theta_{d}$, first, the coordinate of point $\mathrm{C}$ in Figure 1, i.e. $\left(a, \frac{\theta_{d}}{2}\right)$ is substituted in the Kirsch relations (1) to obtain the stresses at this point. Stress values are obtained as follows:

$$
\left\{\begin{array}{l}
\sigma_{\theta \theta}=\left(\sigma_{H}+\sigma_{h}\right)+2\left(\sigma_{H}-\sigma_{h}\right) \cos 2\left(\theta_{d} / 2\right) \\
\tau_{r \theta}=0, \quad \sigma_{r r}=0
\end{array} .\right.
$$

Given that shear stress at this point is zero, $\sigma_{1}=\sigma_{\theta \theta}$ and $\sigma_{3}=\sigma_{r r}=0$ by setting these two values in the failure function of Eqn (5), the following quadratic equation is obtained for $\sigma_{\theta \theta}$ :

$$
\sigma_{\theta \theta}^{2}+A \sigma_{t} \sigma_{\theta \theta}+2 A B \sigma_{t}^{2}=0 \text {. }
$$

By solving this equation, $\sigma_{\theta \theta}$ is obtained:

$$
\sigma_{\theta \theta}=-\sigma_{t}\left(w^{2}-1\right)=-n \sigma_{t}=\sigma_{c} \text {, }
$$

and by setting $\sigma_{\theta \theta}$ from Eqn (6) in this equation and solving for the parameter $\theta_{d}$ :

$$
\theta_{d}=\cos ^{-1} \frac{\frac{\sigma_{c}}{\sigma_{H}}-\left(1+\frac{\sigma_{h}}{\sigma_{H}}\right)}{2\left(1-\frac{\sigma_{h}}{\sigma_{H}}\right)},
$$

where $\theta_{d}$ is the width of the breakout in the borehole wall.
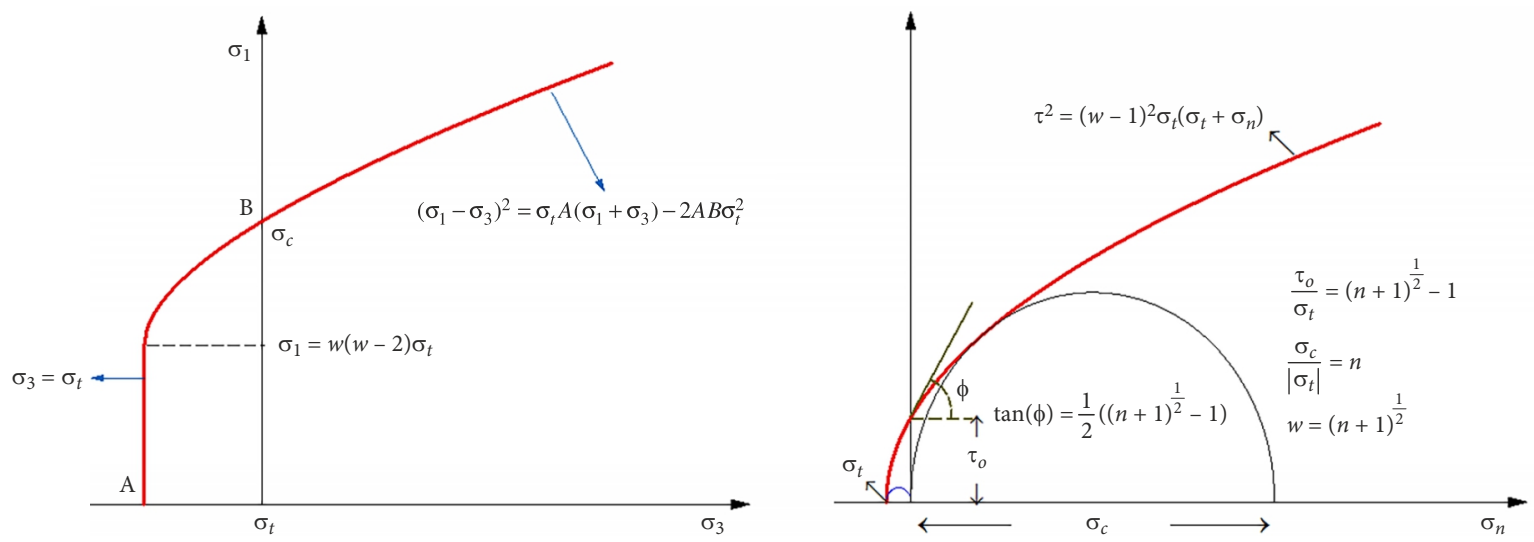

Figure 2. Fairhurst failure function in $\sigma_{1}-\sigma_{3}$ and $\tau-\sigma_{n}$ coordinates 
To obtain the depth of failure in the direction of the minor in situ stress, it is sufficient to set the coordinates of point $\mathrm{D}$ in Figure 1, i.e. $\left(r_{d}, 0\right)$, in the Kirsch relations (1) to obtain the stresses as follows:

$$
\left\{\begin{array}{l}
\sigma_{\theta \theta}=\frac{3}{2}\left(\sigma_{H}-\sigma_{h}\right) \rho^{2}+\frac{1}{2}\left(\sigma_{H}+\sigma_{h}\right) \rho+\sigma_{H} \\
\sigma_{r r}=-\frac{3}{2}\left(\sigma_{H}-\sigma_{h}\right) \rho^{2}+\left(\frac{3}{2} \sigma_{H}-\frac{5}{2} \sigma_{h}\right) \rho+\sigma_{h} \\
\tau_{r \theta}=0
\end{array} .\right.
$$

Again, because the shear stress at this point is zero, $\sigma_{1}=\sigma_{\theta \theta}$ and $\sigma_{3}=\sigma_{r r}$, by setting these stresses in the breakdown function of Eqn (5), the following quartic relation is obtained for the $\rho=\left(a / r_{d}\right)^{2}$ :

$$
\begin{aligned}
& \delta_{1} \rho^{4}+\delta_{2} \rho^{3}+\delta_{3} \rho^{2}+\delta_{4} \rho+\delta_{5}=0 ; \\
& \left\{\begin{array}{l}
\delta_{1}=9\left(\sigma_{H}-\sigma_{h}\right)^{2} \\
\delta_{2}=6\left(\sigma_{H}-\sigma_{h}\right)\left(-\sigma_{H}+3 \sigma_{h}\right) \\
\delta_{3}=\left(-\sigma_{H}+3 \sigma_{h}\right)^{2}+6\left(\sigma_{H}-\sigma_{h}\right)^{2} \\
\delta_{4}=2\left(-\sigma_{H}+3 \sigma_{h}\right)\left(\sigma_{H}-\sigma_{h}\right)+2\left(\sigma_{H}-\sigma_{h}\right) \sigma_{t} A \\
\delta_{5}=\left(\sigma_{H}-\sigma_{h}\right)^{2}+\left(\sigma_{H}+\sigma_{h}\right)
\end{array} .\right.
\end{aligned}
$$

The solution of this equation is done by Newton-Raphson method in MATLAB software.

\section{Theoretical model of breakout failure based on Hoek-Brown failure criterion}

Hoek-Brown failure relationship using the Griffith criterion is also expressed as follows (Hoek \& Brown, 1980; Hoek, 1983):

$$
\sigma_{1}=\sigma_{3}+\sigma_{c}\left(\left(m_{i} \sigma_{3} / \sigma_{c}\right)+1\right)^{05}
$$

where $\sigma_{c}$ is the uniaxial compressive strength of the intact rock and $m_{i}$ is material empirical constant which is dimensionless. Failure function, $F$, for the Hoek-Brown criteria to estimate the shear fracture is defined as:

$$
F_{H B}=\left(\sigma_{1}-\sigma_{3}\right)^{2}-m_{i} \sigma_{c} \sigma_{3}-\sigma_{c}^{2}=0 .
$$

To calculate the width of the breakout in the borehole wall, similar to the procedure performed for the Fairhurst criterion, here the principal stresses obtained from Eqn (6) are substituted in the failure function presented in Eqn (13). The following simple relation is obtained:

$$
\sigma_{\theta \theta}=\frac{1}{2}\left[2\left(\sigma_{H}+\sigma_{h}\right)+4\left(\sigma_{H}-\sigma_{h}\right) \cos 2\left(\frac{\theta_{d}}{2}\right)\right]=\sigma_{c} \text {. }
$$

Solving this equation leads to the following expression for the width of breakout:

$$
\theta_{d}=\cos ^{-1} \frac{\frac{\sigma_{c}}{\sigma_{H}}-\left(1+\frac{\sigma_{h}}{\sigma_{H}}\right)}{2\left(1-\frac{\sigma_{h}}{\sigma_{H}}\right)} .
$$

By setting the coordinates of point D of Eqn (10), in the failure function of Eqn (13), the following quartic equation is obtained for $\rho=\left(a / r_{d}\right)^{2}$, which is solved by Newton-Raphson method in MATLAB software to find the depth of the failure region along the minor in situ stress:

$$
\eta_{1} \rho^{4}+\eta_{2} \rho^{3}+\eta_{3} \rho^{2}+\eta_{4} \rho+\eta_{5}=0
$$

where

$$
\begin{aligned}
& \left\{\begin{array}{l}
\eta_{1}=9\left(\sigma_{H}-\sigma_{h}\right)^{2} \\
\eta_{2}=6\left(\sigma_{H}-\sigma_{h}\right)\left(-\sigma_{H}+3 \sigma_{h}\right) \\
\eta_{3}=\left(-\sigma_{H}+3 \sigma_{h}\right)^{2}+6\left(\sigma_{H}-\sigma_{h}\right)^{2}-\frac{3}{2}\left(\sigma_{H}-\sigma_{h}\right)^{2} \\
\eta_{4}=2\left(-\sigma_{H}+3 \sigma_{h}\right)\left(\sigma_{H}-\sigma_{h}\right)+\frac{1}{2}\left(3 \sigma_{H}-5 \sigma_{h}\right) \\
\eta_{5}=\sigma_{h}
\end{array}\right. \\
& \text { and } \rho=\left(a / r_{d}\right)^{2} \text {. }
\end{aligned}
$$

\section{Results and discussion}

To investigate the results in this part of the article, Carrara marble has been selected. Marble rock samples were relatively homogeneous and isotropic and had very low porosity. The average grain size in the samples was $250 \mu \mathrm{m}$ (Ramsey \& Chester, 2004).

Figure 3 shows the results of confined tensile and triaxial compression tests on marble samples performed by Ramsey and Chester (2004). In this figure, the envelopes of Hoek-Brown and Fairhurst generalized failure criteria fitting on the laboratory results are also shown. As can be seen in Figure 1, in terms of absolute magnitude, the Hoek-Brown criterion suggests higher tensile strength for the specimens, which is almost twice what is shown in the tension cutoff of the Fairhurst criterion.

Each failure envelope divides the coordinate space into three regions; below the curve, exactly on the curve and above the curve. If the stress state at a point around the borehole due to the disturbance of the initial stress state located above the failure curve, the rock has failed at that point. Depending on the position of the point relative to the failure curve, the failure can be tensile or shear. And if the stress state is at a point exactly on the failure envelope, it means that that point is on the threshold of damage. And the points below the curve remain intact.

Now, by solving the theoretical relations obtained for both criteria and using the programs written in MATLAB software, the results are analyzed. Figure 4 shows the changes in the width of the breakout in the borehole wall versus the ratio of in situ stresses. As can be seen, with increasing the ratio of in situ stresses, the width of the breakout increases. Also, both criteria in relation to the width of the breakout failure zone are well compatible with each other. By comparing Eqns (9) and (15), it is observed that the failure width relationship is the same in both criteria. As it is seen failure width depends on the ratio of in-situ stresses and compressive strength of the rock, and since according to Table 1 the values of uniaxial compressive strength for both criteria are close to each other, the diagrams in Figure 4 overlap. 


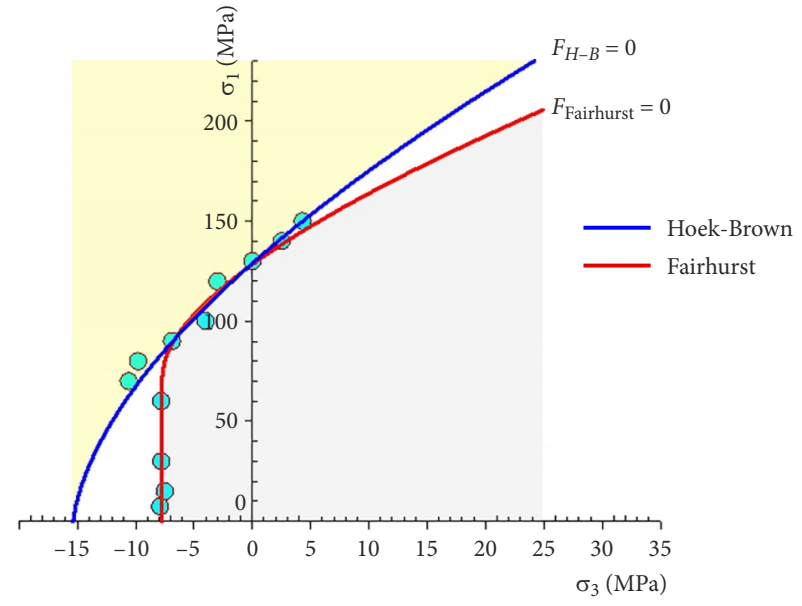

Figure 3. Failure envelopes based on Hoek-Brown and Fairhurst criteria for Carrara marble

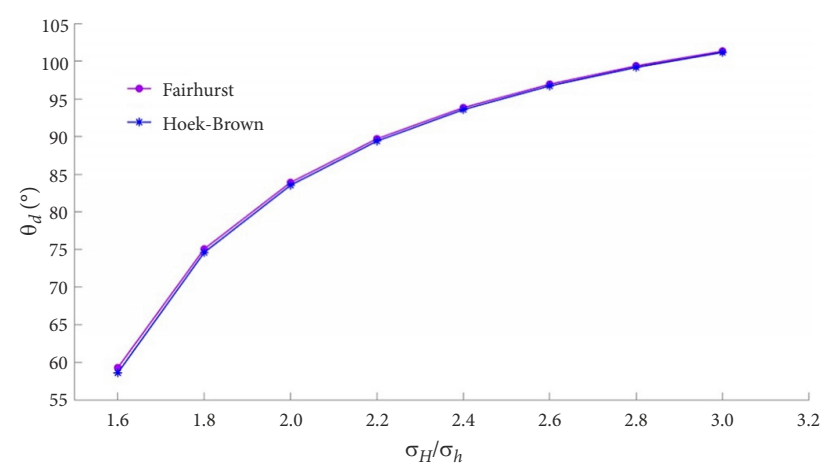

Figure 4. Breakout width changes versus in- situ stress ratio

Table 1. Mechanical properties obtained by fitting the points obtained from confined tensile and triaxial compression tests on marble samples on failure curves (Hoek \& Martin, 2014)

\begin{tabular}{|c|c|c|c|c|c|}
\hline \multicolumn{3}{|c|}{ Fairhurst criterion } & \multicolumn{3}{c|}{ Hoek-Brown criterion } \\
\hline$\sigma_{c}(\mathrm{MPa})$ & $\sigma_{t}(\mathrm{MPa})$ & $\sigma_{c} /\left|\sigma_{t}\right|$ & $\sigma_{c}(\mathrm{MPa})$ & $\sigma_{t}(\mathrm{MPa})$ & $m_{i}$ \\
\hline 128.5 & -7.74 & 16.6 & 129 & -15.6 & 8.25 \\
\hline
\end{tabular}

Figure 5 shows the changes in the depth of the breakout failure zone along the minimum in situ stress versus the ratio of in-situ stresses. The depth of breakout in this diagram is normalized by the borehole radius. It is observed that with increasing the ratio of in situ stresses, the depth of breakout has increased. Also, unlike the previous Figure here, the Fairhurst criterion predicts a greater depth of breakout than the Hoek-Brown criterion, which increases the difference between the two criteria by increasing the ratio of in situ stresses.

Since the pressure inside the borehole is zero, the rock in the borehole wall is in uniaxial compressive state and its failure is controlled by uniaxial compressive strength, and since, according to Figure 3, the same uniaxial compressive strength of both criteria for Carrara marble is obtained, both of which offer the same breakout width.

But by moving away from the borehole wall, the rock changes from a uniaxial stress to a three axial stress. That

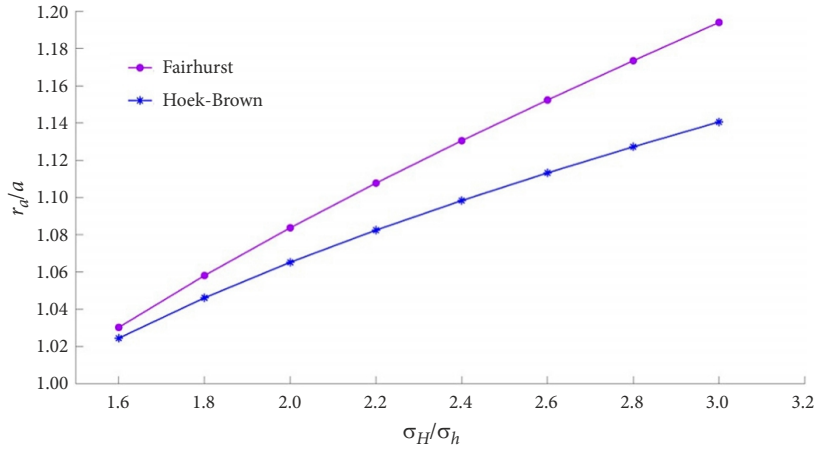

Figure 5. Changes in normalized breakout failure depth versus in situ stress ratios $\left(\sigma_{h}=10 \mathrm{MPa}=c t e\right)$

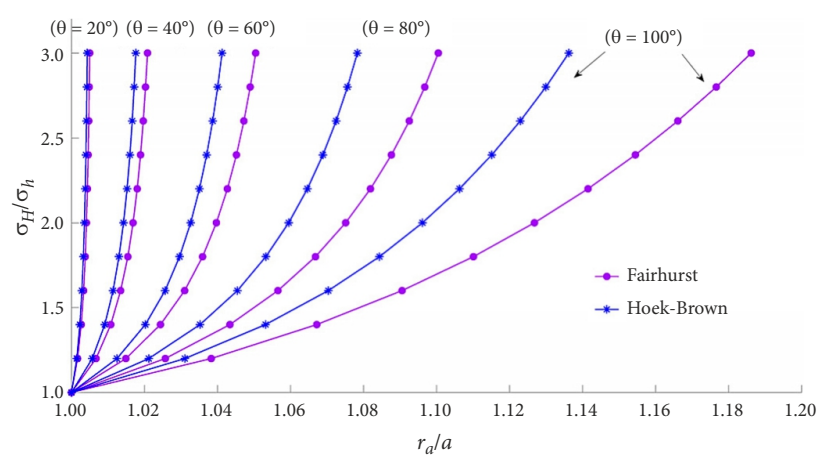

Figure 6. Variations in the ratio of in situ stresses versus failure depths for different breakout width values

is, according to the graphs in Figure 3, the shear controls the failure in the rock. Because in the shear section, the Hoek-Brown criterion shows higher shear strength for the Carrara marble, for a certain in-situ stress ratio, a smaller breakout failure depth is obtained from this criterion compared to the Fairhurst criterion, and as the in situ stress ratio increases, the difference between the two criteria increases.

Figure 6 shows the changes in the ratio of in-situ stresses versus failure depths for different values of failure widths for the Hoek-Brown and Fairhurst criteria. These graphs are basically the sum of the previous two figures. It is observed that in the case of stress ratios close to one, i.e. in the case of isotropic in situ stresses, no damage occurs around the borehole. However, as the stress ratio increases, the failure depth increases and the failure depth changes for larger failure widths are greater. Also, as mentioned earlier, for a given ratio of in situ stress and failure width, the Fairhurst criterion predicts greater failure depth.

Figure 7 shows the failure zone boundary for a minor in situ stress with a constant value of $\sigma_{h}=10 \mathrm{MPa}$ and different values of major in situ stresses for the Carrara marble rock and for both failure criteria. As can be seen for higher values of major in situ stresses, the depth of breakout failure at the corners is greater than the depth of breakout failure along the minor in situ stress. In these cases, although the failure width obtained on the basis of the two criteria is the same, the Fairhurst criterion shows greater breakout depth. It is noteworthy that along with 


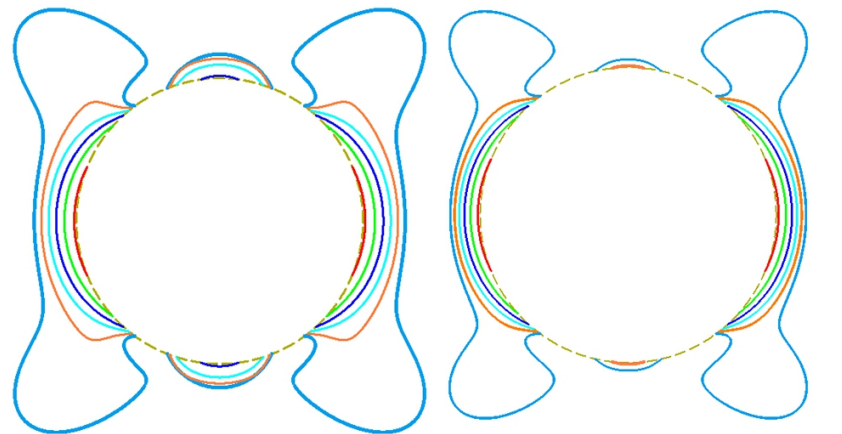

\begin{tabular}{|c|c|c|c|}
\cline { 2 - 4 } \multicolumn{1}{c|}{} & $\sigma_{H}(\mathrm{MPa})$ & $\theta_{d}\left({ }^{\circ}\right)$ & $r_{d}(m)$ \\
\hline- & 60 & 44.56 & 0.011167 \\
\hline- & 80 & 83.90 & 0.011921 \\
\hline- & 100 & 95.49 & 0.012557 \\
\hline & 120 & 101.35 & 0.013134 \\
\hline & 140 & 104.92 & 0.013684 \\
\hline & 160 & 107.33 & 0.014228 \\
\hline
\end{tabular}

Fairhurst Criterion

\begin{tabular}{|c|c|c|c|}
\cline { 2 - 4 } \multicolumn{1}{c|}{} & $\sigma_{H}(\mathrm{MPa})$ & $\theta_{d}\left({ }^{\circ}\right)$ & $r_{d}(m)$ \\
\hline- & 60 & 43.53 & 0.011134 \\
\hline- & 80 & 83.54 & 0.011717 \\
\hline- & 100 & 95.25 & 0.012165 \\
\hline- & 120 & 101.17 & 0.012546 \\
\hline- & 140 & 104.77 & 0.012889 \\
\hline & 160 & 107.20 & 0.013209 \\
\hline & \multicolumn{3}{|c}{}
\end{tabular}

Figure 7. Curves defining the breakout failure area $\left(\sigma_{h}=10 \mathrm{MPa}=c t e\right)$

the breakout, the tensile failure zone is also observed along the major in situ stress. According to the HoekBrown failure criterion, the tensile failure zone occurs for major principal stresses greater than $140 \mathrm{MPa}$ and according to the Fairhurst criterion, the area of tensile failure occurs at major principal stresses greater than $100 \mathrm{MPa}$. In other words, because the Fairhurst failure criterion provides a lower tensile strength for the Carrara marble rock, therefore, for a certain amount of in situ stresses, the tensile failure area obtained from the Fairhurst criterion is larger than the tensile failure area obtained from the Hoek-Brown criterion.

\section{Comparison with laboratory results on Westerly granite}

In this part of the paper, the depth of failure obtained from laboratory results (Song, 1998) is compared with the results obtained from theoretical solution in this paper with two criteria, Hoek-Brown and Fairhurst. The specimens tested in the experiments were Westerly granite. Westerly granite is a crystalline rock that is often used in laboratory studies and has the composition of Table 2 in terms of mineral type. The granite tested in experimental studies has been assumed to be homogeneous, isotropic and elastic and is therefore suitable for comparing the results with the theoretical solution results presented in this paper. The mechanical properties of Westerly granite are obtained using Brazilian tensile strength tests and uniaxial compressive strength tests according to Table 3 . These parameters have been used in the theoretical models of this section.

Figure 8 and Figure 9 show the changes in normalized failure depth versus major in situ stress and for two dif-
Table 2 . Westerly granite mineral compounds (Feininger, 1968)

\begin{tabular}{|l|c|}
\hline \multicolumn{1}{|c|}{ Mineral type } & Volume in percentage \\
\hline Quartz & 27.5 \\
\hline Microcline & 34.4 \\
\hline Plagioclase & 32.4 \\
\hline Muscovite & 1.3 \\
\hline Biotite & 3.2 \\
\hline Opaque accessories & 0.8 \\
\hline Other accessories & 0.4 \\
\hline
\end{tabular}

Table 3. Mechanical properties of Westerly granite (Song, 1998)

\begin{tabular}{|l|c|c|}
\hline \multicolumn{1}{|c|}{ Property } & Value & symbol \\
\hline $\begin{array}{l}\text { Uniaxial compressive } \\
\text { strength }(\mathrm{MPa})\end{array}$ & 187 & $\sigma_{c}$ \\
\hline $\begin{array}{l}\text { Brazilian tensile } \\
\text { strength }(\mathrm{MPa})\end{array}$ & 8.25 & $\sigma_{t}$ \\
\hline $\begin{array}{l}\text { Hoek-Brown constant } \\
\text { coefficient }\end{array}$ & 22.66 & $m_{i} \approx \sigma_{c} /\left|\sigma_{t}\right|(\mathrm{Cai}, 2010)$ \\
\hline
\end{tabular}

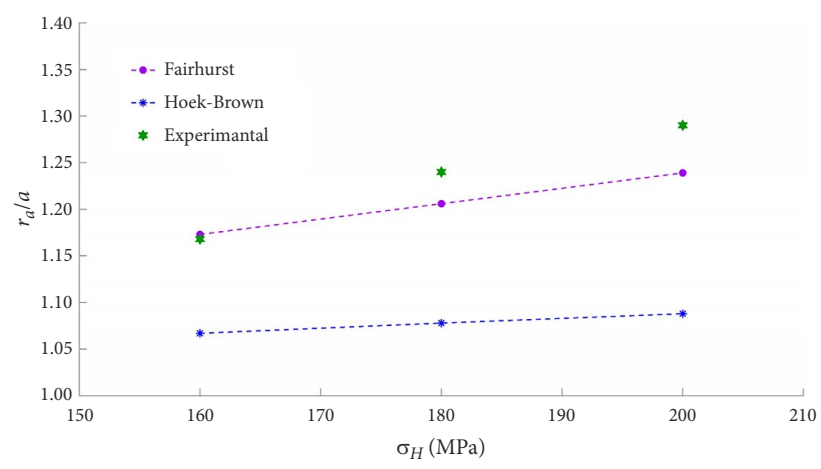

Figure 8. Normalized breakout failure depth versus major in situ stress $\sigma_{h}=20 \mathrm{MPa}$

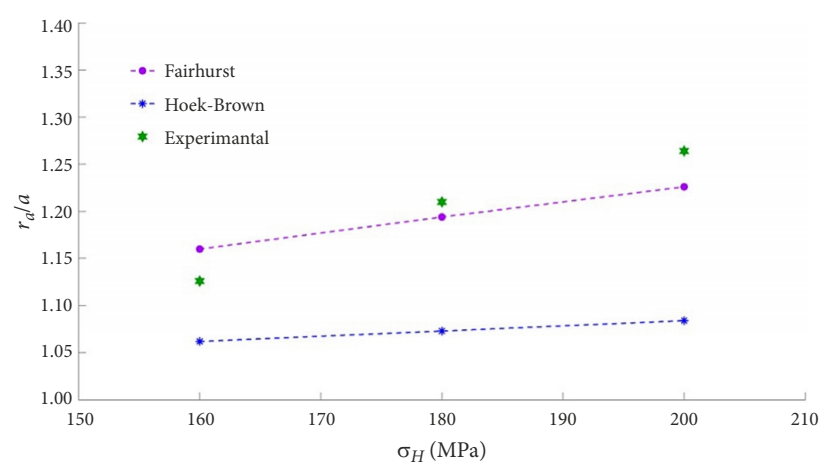

Figure 9. Normalized breakout failure depth versus major in situ stress $\sigma_{h}=50 \mathrm{MPa}$

ferent values of minor in situ stress. As can be seen, the theoretical analysis based on the Fairhurst criterion is in good agreement with the results of laboratory model on Westerly granite. Figure 10 shows breakout cross-sectional shape obtained from the Song's laboratory studies. 

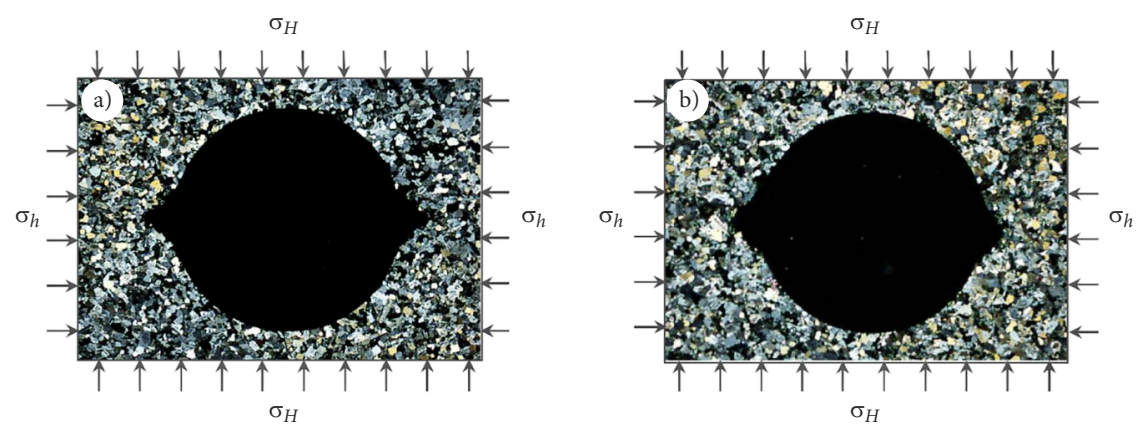

Figure 10. Breakout cross-sectional shape obtained from laboratory experiments: (a) prestressed test; (b) predrilled test $\left(\sigma_{H}=200 \mathrm{MPa}, \sigma_{h}=50 \mathrm{MPa}\right.$ (Song, 1998))

\section{Conclusions}

In this paper, the theoretical model of breakout failure around the borehole was obtained based on the two criteria of Fairhurst and Hoek-Brown.

According to the results, it was observed that:

- In general, if the in situ stresses around the borehole are isotropic, no failure is observed around the borehole, and as the ratio of in situ stresses increases, the failure width in the borehole wall and the depth of failure along the minor in situ stress increase.

- As the ratio of in situ stresses increases, the failure area around the borehole expands so that the depth of failure at the corners becomes deeper than the depth of failure along the minor in situ stress.

- The width of breakout in the borehole wall obtained from the two criteria of Fairhurst and Hoek-Brown for different ratios of in situ stresses, are well compatible with each other, although the depth of failure along the minor in situ stress obtained from Fairhurst criterion is greater than the depth of failure obtained from the Hoek-Brown criteria for Carrara marble, and with increasing the ratio of in situ stresses, the difference between the values obtained from the two criteria increases.

- As the in situ stress ratio increases, tensile fracture is also observed along the major in situ stress, and since the Fairhurst criterion suggests less tensile strength than the Hoek-Brown criterion, for a given in situ stress ratio, the tensile failure region obtained from the Fairhurst criterion is wider and deeper than the failure area obtained from the Hoek-Brown criteria for Carrara marble.

- By comparing the laboratory results on Westerly granite with the results of the theoretical model in this paper, a good agreement was observed for the breakout depth.

\section{References}

Abbas, A. K., Flori, R. E., \& Alsaba, M. (2019). Stability analysis of highly deviated boreholes to minimize drilling risks and nonproductive time. Journal of Energy Resources Technology, 141(8), 082904. https://doi.org/10.1115/1.4042733
Abdelghany, W. K., Radwan, A. E., Elkhawaga, M. A., Wood, D. A., Sen, S., \& Kassem, A. A. (2021). Geomechanical modeling using the depth-of-damage approach to achieve successful underbalanced drilling in the Gulf of Suez rift basin. Journal of Petroleum Science and Engineering, 202, 108311. https://doi.org/10.1016/j.petrol.2020.108311

Bell, J. S., \& Gough, D. I. (1979). Northeast-southwest compressive stress in Alberta evidence from oil wells. Earth and Planetary Science Letters, 45(2), 475-482.

https://doi.org/10.1016/0012-821X(79)90146-8

Brudy, M., Zoback, M. D., Fuchs, K., Rummel, F., \& Baumgärtner, J. (1997). Estimation of the complete stress tensor to $8 \mathrm{~km}$ depth in the KTB scientific drill holes: Implications for crustal strength. Journal of Geophysical Research: Solid Earth, 102(B8), 18453-18475. https://doi.org/10.1029/96JB02942

Cai, M. (2010). Practical estimates of tensile strength and HoekBrown strength parameter $m_{i}$ of brittle rocks. Rock Mechanics and Rock Engineering, 43(2), 167-184.

https://doi.org/10.1007/s00603-009-0053-1

Carr, W. J. (1974). Summary of tectonic and structural evidence for stress orientation at the Nevada Test Site (74-176).

http://pubs.er.usgs.gov/publication/ofr74176

Cheng, W., Jiang, G., Zhou, Z., Wei, Z., \& Li, X. (2019). Numerical simulation for the dynamic breakout of a borehole using boundary element method. Geotechnical and Geological Engineering, 37(4), 2873-2881. https://doi.org/10.1007/s10706-019-00802-7

Cox, J. W. (1972). The high-resolution dipmeter reveals diprelated borehole and formation characteristics. Journal of Canadian Petroleum Technology, 11(1), PETSOC-72-01-02. https://doi.org/10.2118/72-01-02

Delonca, A., \& Vallejos, J. A. (2020). Incorporating scale effect into a failure criterion for predicting stress-induced overbreak around excavations. International Journal of Rock Mechanics and Mining Sciences, 127, 104213.

https://doi.org/10.1016/j.ijrmms.2020.104213

Fairhurst, C. (1964). On the validity of the 'Brazilian' test for brittle materials. International Journal of Rock Mechanics and Mining Sciences \& Geomechanics Abstracts, 1(4), 535-546. https://doi.org/10.1016/0148-9062(64)90060-9

Feininger, T. (1968). The updip termination of a large dike of Westerly Granite and the regional distribution of the Westerly and Narragansett Pier Granites in Rhode Island and Connecticut. In Geological survey research (pp. D181-D185). United States Government Printing Office.

Gough, D. I., \& Bell, J. S. (1982). Stress orientations from borehole wall fractures with examples from Colorado, east Texas, and northern Canada. Canadian Journal of Earth Sciences, 19(7), 1358-1370. https://doi.org/10.1139/e82-118 
Haimson, B. (2007). Micromechanisms of borehole instability leading to breakouts in rocks. International Journal of Rock Mechanics and Mining Sciences, 44(2), 157-173.

https://doi.org/10.1016/j.ijrmms.2006.06.002

Haimson, B. C., \& Herrick, C. G. (1985). In-situ stress evaluation from borehole breakouts: experimental studies. In Proceedings of 26th US Symposium on Rock Mechanics (pp. 1207-1218). Rapid City, Balkema, Rotterdam.

Haimson, B. C., \& Herrick, C. G. (1986). Borehole breakouts - a new tool for estimating in situ stress?. In Proceedings of International Symposium on Rock Stress and Rock Stress Measurements (pp. 271-280). Stockholm, Centek Publ., Luleå.

Haimson, B., \& Lee, H. (2004). Borehole breakouts and compaction bands in two high-porosity sandstones. International Journal of Rock Mechanics and Mining Sciences, 41(2), 287301. https://doi.org/10.1016/j.ijrmms.2003.09.001

Haimson, B. C., \& Song, I. (1993). Laboratory study of borehole breakouts in Cordova Cream: a case of shear failure mechanism. International Journal of Rock Mechanics and Mining Sciences \& Geomechanics Abstracts, 30(7), 1047-1056.

https://doi.org/10.1016/0148-9062(93)90070-T

Herrick, C. G., \& Haimson, B. C. (1994, June). Modeling of episodic failure leading to borehole breakouts in Alabama limestone. In 1st North American Rock Mechanics Symposium (Paper Number: ARMA-1994-0217). Austin, Texas.

Hickman, S., \& Zoback, M. (2004). Stress orientations and magnitudes in the SAFOD pilot hole. Geophysical Research Letters, 31(15). https://doi.org/10.1029/2004GL020043

Hoek, E. (1983). Strength of jointed rock masses. Géotechnique, 33(3), 187-223. https://doi.org/10.1680/geot.1983.33.3.187

Hoek, E., \& Brown, E. (1980). Empirical strength criterion for rock masses. Journal of Geotechnical and Geoenvironmental Engineering, 106, 1013-1035. https://doi.org/10.1061/AJGEB6.0001029

Hoek, E., \& Martin, C. D. (2014). Fracture initiation and propagation in intact rock - A review. Journal of Rock Mechanics and Geotechnical Engineering, 6(4), 287-300. https://doi.org/10.1016/j.jrmge.2014.06.001

Huber, K., Fuchs, K., Palmer, J., Roth, F., Khakhaev, B. N., VanKin, L. E., Pevzner, L. A., Hickman, S., Moos, D., Zoback, M. D. \& Schmitt, D. (1997). Analysis of borehole televiewer measurements in the Vorotilov drillhole, Russia - first results. Tectonophysics, 275(1-3), 261-272.

https://doi.org/10.1016/S0040-1951(97)00031-0

Jaeger, J. C., Cook, N. G., \& Zimmerman, R. (2009). Fundamentals of rock mechanics. John Wiley \& Sons.

Lakirouhani, A., Asemi, F., Zohdi, A., Medzvieckas, J., \& Kliukas, R. (2020). Physical parameters, tensile and compressive strength of dolomite rock samples: influence of grain size. Journal of Civil Engineering and Management, 26(8), 789-799. https://doi.org/10.3846/jcem.2020.13810

Lakirouhani, A., Detournay, E., \& Bunger, A. P. (2016). A reassessment of in situ stress determination by hydraulic fracturing. Geophysical Journal International, 205(3), 1859-1873. https://doi.org/10.1093/gji/ggw132

Lee, M., \& Haimson, B. (1993). Laboratory study of borehole breakouts in Lac du Bonnet granite: a case of extensile failure mechanism. International Journal of Rock Mechanics and Mining Sciences \& Geomechanics Abstracts, 30(7), 1039-1045. https://doi.org/10.1016/0148-9062(93)90069-P

Leeman, E. R. (1964a). The measurement of stress in rock: Part I: The principles of rock stress measurements. Journal of the Southern African Institute of Mining and Metallurgy, 65(2), 45-81. https://doi.org/10.10520/AJA0038223X_4882
Leeman, E. R. (1964b). The measurement of stress in rock: Part II: Borehole rock stress measuring instruments. Journal of the Southern African Institute of Mining and Metallurgy, 65(2), 82-114. https://doi.org/10.10520/AJA0038223X_4883

Leeman, E. R. (1964c, October). Absolute rock stress measurements using a borehole trepanning stress-relieving technique. In The 6th U.S Symposium on Rock Mechanics (USRMS) (Paper Number: ARMA-64-407). Rolla, Missouri, USA

Lin, H., Kang, W. H., Oh, J., \& Canbulat, I. (2020). Estimation of in-situ maximum horizontal principal stress magnitudes from borehole breakout data using machine learning. International Journal of Rock Mechanics and Mining Sciences, 126, 104199. https://doi.org/10.1016/j.ijrmms.2019.104199

Mastin, L. G. (1984). Development of borehole breakouts in sandstone [MSc thesis]. Stanford University, Palo Alto.

Martin, C. D., Martino, J. B., \& Dzik, E. J. (1994, August). Comparison of borehole breakouts from laboratory and field tests. In Rock Mechanics in Petroleum Engineering (Paper Number: SPE-28050-MS). Delft, Netherlands.

https://doi.org/10.2118/28050-MS

Okland, D., \& Cook, J. M. (1998, July). Bedding-related borehole instability in high-angle wells. In SPE/ISRM Rock Mechanics in Petroleum Engineering (Paper Number: SPE-47285-MS). Trondheim, Norway. https://doi.org/10.2118/47285-MS

Ramsey, J. M., \& Chester, F. M. (2004). Hybrid fracture and the transition from extension fracture to shear fracture. Nature, 428, 63-66. https://doi.org/10.1038/nature02333

Reinecker, J., Heidbach, O., Tingay, M., Sperner, B., \& Müller, B. (2005). The release 2005 of the World Stress Map. http://www.world-stress-map.org/

Setiawan, N. B., \& Zimmerman, R. W. (2018). Wellbore breakout prediction in transversely isotropic rocks using true-triaxial failure criteria. International Journal of Rock Mechanics and Mining Sciences, 112, 313-322.

https://doi.org/10.1016/j.ijrmms.2018.10.033

Shalev, E., Bauer, S. J., Homel, M. A., Antoun, T. H., Herbold, E. B., Vorobiev, O. Y., Levin, H., Oren, V., \& Lyakhovsky, V. (2021). Borehole breakout modeling in arkose and granite rocks. Geomechanics and Geophysics for Geo-Energy and Geo-Resources, $7(1), 15$. https://doi.org/10.1007/s40948-021-00215-y

Shamir, G., \& Zoback, M. D. (1992). Stress orientation profile to $3.5 \mathrm{~km}$ depth near the San Andreas Fault at Cajon Pass, California. Journal of Geophysical Research: Solid Earth, 97(B4), 5059-5080. https://doi.org/10.1029/91JB02959

Song, I. (1998). Borehole breakouts and core disking in Westerly granite: Mechanisms of formation and relationship to in situ stress (Publication No. AAI9825734) [Doctoral dissertation, Wilmington University]. ProQuest Dissertations \& Theses Global.

Song, I., \& Haimson, B. C. (1997). Polyaxial strength criteria and their use in estimating in situ stress magnitudes from borehole breakout dimensions. International Journal of Rock Mechanics and Mining Sciences, 34(3-4), 116.e1-116.e16. https://doi.org/10.1016/S1365-1609(97)00240-2

Syarifuddin, N., \& Busono, I. (1999). Regional stress alignments in the Kutai Basin, East Kalimantan, Indonesia: a contribution from a borehole breakout study. Journal of Asian Earth Sciences, 17(1), 123-135.

https://doi.org/10.1016/S0743-9547(98)00049-X

van den Hoek, P. J. (2001, July). Prediction of different types of cavity failure using bifurcation theory. In The 38th U.S. Symposium on Rock Mechanics (USRMS) (Paper Number: ARMA01-0045). DC Rocks 2001, Washington, D.C. 
Wu, H., Guo, N., \& Zhao, J. (2017). Borehole instabilities in granular rocks revisited: A multiscale perspective. In E. Papamichos, P. Papanastasiou, E. Pasternak, \& A. Dyskin A. (Eds.), Bifurcation and degradation of geomaterials with engineering applications (IWBDG 2017). Springer Series in Geomechanics and Geoengineering. Springer, Cham.

https://doi.org/10.1007/978-3-319-56397-8_54

Yousefian, H., Fatehi Marji, M., Soltanian, H., Abdollahipour, A., \& Pourmazaheri, Y. (2020). Wellbore trajectory optimization of an Iranian oilfield based on mud pressure and failure zone. Journal of Mining and Environment, 11(1), 193-220. https://doi.org/10.22044/jme.2020.8779.1768

Zoback, M. D., Moos, D., Mastin, L., \& Anderson, R. N. (1985). Well bore breakouts and in situ stress. Journal of Geophysical Research, 90(B7), 5523-5530. https://doi.org/10.1029/JB090iB07p05523

Zoback, M. D., Barton, C. A., Brudy, M., Castillo, D. A., Finkbeiner, T., Grollimund, B. R., Moos, D. B., Peska, P., Ward, C. D., \& Wiprut, D. J. (2003). Determination of stress orientation and magnitude in deep wells. International Journal of Rock Mechanics and Mining Sciences, 40(7), 1049-1076.

https://doi.org/10.1016/j.ijrmms.2003.07.001 